\title{
Integration of Islamic Perspectives into Medical Imaging Curriculum: an Outcome Based Education Approach
}

\author{
Zainul Ibrahim Zainuddin \\ Kulliyyah of Allied Health Sciences, International Islamic University Malaysia Kuantan .
}

\begin{abstract}
This paper presents a conceptual approach to the integration of Islamic perspectives into a Medical Imaging Curriculum to the concept of Outcome-Based Education (OBE). This work is seen within the context of harmonising Islamic principles to a currently accepted concept in education. Although there have been discussions that question the concept of OBE, this paper contends that the integration can benefit from the practicality aspect of OBE. This can reduce the complexities and fatigue in addressing the integration using an educational approach that is different to that being applied to the human sciences. This paper features the main elements in $\mathrm{OBE}$ in the form of Islamic programme educational objectives, Islamic programme outcomes, and Islamic domain learning outcomes. The justification to use domain learning outcomes instead of course learning outcome is given. The teaching and learning strategies, as well as the assessment, are examined through a lens that serves to provide a desirable, practical and holistic model of Islamic integration. It is felt that the currently accepted teaching and assessment methodologies can be adapted for the integration exercise. This work also highlights two often overlooked elements of OBE; teacher and student characteristics. The various terminologies that describe the Islamic teacher characteristics and the differences in student learning styles and preferences are presented. Furthermore, suggestions are made to align the assessment of the integration to various taxonomies of learning, with the aim in evaluating the internalisation of the Islamic essences. This work contents that a holistic approach towards integration of Islamic perspectives into Medical Imaging curriculum can be realised.
\end{abstract}

KEYWORDS: Islamic perspectives; Outcome Based Education; Teacher characteristics; learning styles; Medical imaging

\section{INTRODUCTION}

The integration of Islamic perspectives into the theory and practice of various professions are actively being undertaken. These are manifestations of the formulation of the concept of Islamisation of Knowledge in the 1960s. In 1977, the First World Conference on Muslim Education held in Makkah passed an important resolution that called for efforts to be made to establish a symbiotic relationship between Revealed Knowledge and acquired knowledge. Subsequently, an increase in journal articles imbued with Islamic perspectives was noted from $1977 .^{1}$

Compartmentalisation of the contrasting and the dualism in knowledge in institutes of higher education has led to dissatisfaction and anxieties among the Muslim graduates to face contemporary issues in the light of the Islamic worldview. ${ }^{2}$ This led to efforts to integrate Islamic perspectives within the curriculum as seen in the efforts of various

Zainul Ibrahim Zainuddin

Department of Diagnostic Imaging and Radiotherapy,

Kulliyyah of Allied Health Sciences,

International Islamic University Malaysia,

Kuantan Campus.

Email: zainul@iium.edu.my institutions of higher learning. The idea of curriculum integration between Islamic revealed knowledge and human sciences can be traced to Bediuzamman Said Nursi (1877-1960), who's interest in reconciling faith and reason, and Islam and science. ${ }^{3}$ These are manifested in his words; "The lack of the modern sciences causes fanatism, while the lack of religious sciences causes scepticism."

Integration attempts that have been made include the introduction of Islamic concepts and Islamic Arabic terms, concepts of Iman (in terms of spiritual needs and spirituality), religious rituals, the stories of the Prophets, making references to relevant Quranic verses and Hadith. ${ }^{5}$ However to some, these approaches failed to address the core issues of the paradigms and methodologies in the disciplines. ${ }^{6}$ The present author posits that these "failed" approaches should not deter further efforts towards realising the integration ventures. Whatever "little" success that results from these ventures should be taken in the spirit of propagating Islamic ideals as espoused by Prophet Muhammad (Pbuh).

A holistic integration of Islamic perspectives within a given profession should be initiated from the foundation studies. This is important for the integration initiative at foundation level serves to prepare the future practitioner with the religious 
knowledge and approaches in the face of contemporary issues in the various theoretical and practice domains of the discipline. Furthermore, in view of the multi-racial, multi-cultural and multireligious environment that are common these days, it would be imperative that the mindsets of these future Muslim be enhanced in terms of Islamic beliefs, values, morals and practices. The subsequent display of the Muslim characteristics would be catalysts to influence the yet to be Muslims to the beauty of the religion. The adopted methodology of integration should also take into consideration an alignment to the present educational paradigm that is being practiced by the particular institution of higher learning. This can reduce the complexities and fatigue in addressing the integration using an educational approach that is different to that being applied to the human sciences.

Outcome-based education (OBE) is currently being adopted worldwide. Developed by William Spady and associates in 1990s, this educational model gives priority to ends, purposes, learning, accomplishments, and results. The features of OBE include the curriculum, instructional strategies, assessments, and performance standards that are developed and implemented to facilitate key outcomes. The features of OBE is described as outcome driven where the outcomes are defined and levels of outcomes identified. ${ }^{7}$ The outcomes, being focussed, involve a design-down approach where the learning content within the discipline is selected based on the desired outcomes. The concept of OBE also emphasises on student-centred learning where OBE focusses on the students by providing them with a direction in achieving specific outcomes for individual learning. ${ }^{8}$

The failures, as well as successes in adopting OBE, have been reported. ${ }^{9}$ Opponents of OBE raised the inappropriate inclusion and emphasis on attitudes and values in the educational model. ${ }^{10}$ There are also concerns in adopting OBE in the face of weak empirical evidence, the doubtful clarity in the applicability of OBE to more complex aspects of clinical performance and placing complex personal and professional attributes as "competencies". ${ }^{11}$ Matters pertaining to assessment in OBE have also become contentious issues. ${ }^{12}$ However, it was concluded that OBE can still provide a valuable approach in defining requisite knowledge and skills, and blueprinting assessments to some important aspects of undergraduate medical education. ${ }^{11}$

The present author holds the belief that OBE can provide a practical approach towards integration of Islamic perspectives into the theories and practice of a profession at its foundation/undergraduate level. This is seen within a harmonising approach between human sciences and Islamic revealed knowledge, using a common and currently accepted educational platform used in the Malaysian educational setting. Furthermore, the concept of "outcome based" is not alien to Islam. There are numerous verses in the Holy Qur'an that relate the concept of outcome in relation to man's deeds, good or evil, in relation to heaven or hell. A prominent verse can be found in Surah Al-Zalzalah 99:7-8; "Then shall anyone who has done an atom's weight of good, see it! And anyone who has done an atom's weight of evil shall see it."13 This verse is complemented by other verses that highlight the virtues of doing the righteous and its rewards of forgiveness and supreme felicity. On the other hand, acts that are considered as wrongdoings are seen within the chastisement in the hellfire. Thus, it can be presented that the outcome based concept in Islam, being revealed in nature, pays particular emphasis on what it takes to ensure an eventual success in the hereafter.

The nature of Medical Imaging include areas that involve the principles and objectives of Healthcare and Medical imaging, patient and patientcare, technical and technology, quality, economic considerations, safety, professionalism and ethics that are unique to the profession. It can be argued that the methodology of integration of Islamic perspectives could also be unique in view of the different domains involved.

This paper attempts to present a conceptual framework for the integration of Islamic inputs into Medical imaging theory by adapting the concept of OBE. An initial understanding of the characteristics of OBE given above is crucial in order to introduce, promote, plan, implement, sustain and evaluate the integration of Islamic perspectives into Medical imaging. The subsequent discussions present the integration of Islamic perspectives within the context of OBE. The term "Integrated Islamic" prefix to Programme Educational Outcomes, Programme Outcomes and Domain Learning Outcomes represent the Islamic adjective to those elements of OBE. The justification for the use of Domain learning outcome instead of Programme learning outcomes is given. To adequately address Islam and its essences into those Medical imaging components will not only complement the efforts in the other disciplines but also enrich the Islamic educational environment.

\section{Adopting OBE in The Integration Of Islamic Perspectives}

For the purpose of this paper, the essential elements of OBE include identification of the needs, the outcomes of the educational process, the curriculum content, the educational and teaching strategies and the assessment methods.

\section{Identification of Needs}

The identification of educational outcomes is important when a new educational program, or a new curriculum, is being discussed. Based on the work of Lawson \& Askell-Williams ${ }^{12}$, questions that include "What should our students be able to do?", "What sort of people do we expect our graduates to be?" are focussed on outcomes. Planning the 
curriculum or the program of study by working backward from those primary objectives creates the important direction "This is what we want to achieve, so what do we need to do to reach those objectives?" The same questions can still be adopted in mapping out the direction for the integration of Islamic Perspectives in Medical imaging. The need is rather straight forward; fulfilling the overall concept of harmonising Islamic revealed knowledge within the human sciences. The following sub-sections will address the other elements of OBE.

\section{Integrated Islamic Programme Educational Objectives (IIPEOs)}

Programme educational objectives (PEO) are broad statements that describe the career and professional achievements of graduates in their career and professional life measured a few years after graduation. ${ }^{8}$ Thus for Medical Imaging graduates, the PEOs are directed towards examining the graduate, now a practitioner, in terms of how he has been able to contribute towards the field of Medical imaging; taking responsibilities, making professional decisions, contributing towards management, lifelong learning, and research.

An example of the Integrated Islamic Programme Educational Objectives (IIPEO) can be aligned to the vision of the International Islamic University Malaysia (IIUM). The university has a vision in its "scope of Islamic education as the process of nurturing the cognitive, affective, spiritual and behavioral aspects of the human personality in the light of Islamic Aqidah (creed), Shari'ah (law) and Akhlaq (ethics)" 14 In the long run, the university hopes that its graduates will serve as professionals in the service of Allah, the cause of Islam and to contribute towards the restoration of the primacy of Islam in all fields of knowledge.

Extending the above objectives to Medical imaging, the proposed IIPEO can be presented as follows:

"The graduate has integrated holistic Islamic essences in their professionalism and working environment. He has demonstrated the Islamic leadership to face and manage contemporary issues related to the discipline in view of the possible / anticipated changes to the discipline and healthcare that is in line with the continuous developments in technologies and professional expectations. It is also expected that the graduates have been able to introduce, promote, change or enhance the mindsets of the professionals in the working environment to the Islamic paradigm and heritage. He should have demonstrated the professional and personal composures in dealing with the realities of the multi-cultural, multi-racial and multi-religious setting both within and outside the professional environments."

Surveys and questionnaires are often the favoured methods to seek opinions from the alumni and employers pertaining to the fulfillment of the PEOs.
It could be anticipated that assessment of IIPEO could be problematic. The common approach to seeking feedback from employers in relation to conventional PEO may not be applicable. Different job areas, different types of institutions, cultural and racial conflicts and religious sentiments could become obstacles towards the optimal application of Islamic approaches by the graduates. Secular administrative stances and socio-political constraints from within the multiracial, multicultural and multi-religious settings in the institutions could be the domineering factor in impeding those religious perspectives to be practiced. The assessment of IIPEO could then be limited to personal experiences and opinions as reported by the graduates themselves.

\section{Integrated Islamic Programme Learning Outcomes (IIPLO)}

Student capability, performance, and knowledge upon completion of the programme are framed in the programme learning outcomes or learning outcomes. ${ }^{8,15}$ In simple terms this reflects on the expected overall knowledge, skills, attributes, behaviours and other professional abilities that the student should demonstrate upon graduation.

This paper proposes the following IIPLOs:

By the end of this programme the students should be able to:

1. Demonstrate comprehensive Islamic knowledge that is relevant to Medical imaging.

2. Establish oneself as a healthcare professional whose conduct is in accordance with the Islamic morals, values, and conduct.

3. Demonstrate sensitivities towards religious beliefs and cultural differences of others as outlined by Islam.

4. Manage information in terms of validity and proper dissemination while preserving the private information of others.

5. Able to apply the basic Islamic principles in managing issues in Medical imaging.

Demonstrate Islamic leadership, teamwork, independence and effective interpersonal communication skills in the daily professional activities.

Able to conduct research in the spirit of enhancing knowledge as championed by Islam.

\section{Justification for Domain outcomes}

It is common to find in discussions that relate to OBE the term "course outcomes" being used interchangeably with the terms "learning outcomes" and "learning objectives". Collectively, they refer to the knowledge, skills and competencies, including the social dimensions that a learner should be able to do upon completion of a course or module. ${ }^{16}$ The elements within these terms allow communication with others, especially students, about the content and intent of a 
teaching activity or curriculum. ${ }^{17}$ This guides the teacher in determining the best teaching practices and the student with the focus in their studies.

The Malaysian Qualification Agency (MQA) lists 8 fundamental modules and 26 professional modules for a typical Medical imaging programme. ${ }^{18}$ The nature of these modules range from understanding the physics applicable to the discipline, human interactions, handling of imaging equipment to ensuring the safety features involved in the imaging procedures. Besides those modules, graduates need to undergo Clinical training that provides the avenues for the students to apply learned theories into the clinical setting. Some amount of overlapping of the theoretical components in these modules is evident. For example, general aspects involving safety can be seen in at least nine professional modules which include patientcare, specialised imaging procedures, four specialised imaging modalities, comparative imaging, Evidencebased practice in Medical Imaging and Professionalism and Ethics in Medical imaging.

This paper contends that the theoretical and practical modules listed by MQA above can be reclassified into several theoretical domains. They are (1) Basics in healthcare and Medical Imaging, (2) patient-care, (3) use of technology, (4) technicalities or procedural, (5) quality, (6) safety, (7) economy, (8) research and (9) professionalism. Primarily, this re-classification is adopted to streamline the identification of modules, and its content, with similar domain outcomes. Using the safety domain as an example, the practicality in using the theoretical domains is seen within the "macro" and "micro" concepts.

All discussions pertaining to safety aspect in all the modules will be preceded with the general overview of safety from Islamic standpoints. This forms the "macro" dimension. The "micro" concepts refer to the specific concepts of safety that are highlighted within the individual modules. Examples include the aspects involving the prevention of cross-infection and radiation safety. Thus the micro concepts refer to the specific concepts that are unique to a given module, yet remains under the main theoretical domain, safety. The concept of individual tailoring of Islamic perspectives to the macro and micro concepts within the safety domain will then apply. By presenting all safety considerations in its respective domain, the academicians, students and serving practitioners will have an understanding of the overall Islamic approach towards addressing all safety issues in the discipline. Thus the present author contents that it will be more practical to address the outcomes in relation to the domains. The term "Integrated Islamic Domain Outcomes (IIDO)" is used in the ensuing discussions.

The approach to use the domains outcomes are further justified below:

A team-work approach can be garnered within the members of the faculty to identify the relevant Islamic viewpoints in each theoretical domain. The involvement of a combination of experts that include those well-versed in Islamic theology, philosophy, pedagogy and social sciences would be advantageous. With more inputs from the team, a thorough coverage of Islamic inputs can be expected.

Standardisation of Islamic perspectives can be achieved and it will be spread out throughout the study period. The mention of Islamic perspective relevant to the macro component of the safety domain in the various modules is not taken as repetition. Rather it should be viewed as "reinforcement" of knowledge, a concept well established in education. Furthermore, it is common for modules within the curriculum are taught by different academicians. Thus there is the avenue that the "reinforcement of Islamic perspectives" pertaining to the same domain in another module by a different academician, could be the catalyst for internalising the "reinforcement" by the students.

Changes in the scheduling of modules during the studies do not interfere with the delivery of Islamic inputs. The integration exercise, using the agreed standardised inputs, by different lecturers, can ensure constant and equal coverage throughout their four years study. It is felt that by addressing the Islamic viewpoints based on the domains, the methodology for assessment can be standardised. Using the same standardised approach is seen within the context of reinforcement of knowledge. It is proposed that written assignments or learning portfolios can be used for the assessment.

\section{Integrated Islamic Domain synopsis (IIDS)}

A course synopsis describes the course in terms of the overall goal of the course, the main topics covered, the importance of the course to students, and the instructional methods to be used.

An example of IIDS that using the safety domain:

There are various safety considerations that exist in Medical imaging. They can be seen from the types, their manifestations and ways in limiting the risks. The Islamic perspectives towards managing these risks are presented. This is to enable the students to personalize and internalise the Islamic approaches with the aim to limit those risks to the patient and other individuals.

\section{Integrated Islamic Domain outcomes (IIDO) This paper proposes the following Integrated Islamic Domain outcomes:}

identify the macro and micro concepts pertaining to safety in Medical imaging

relate those macro and micro concepts in safety to Islamic essences

internalise the Islamic approach towards the various concepts in safety in Medical imaging 
demonstrate the Islamic approach towards the preservation and enhancement of the Islamic approach to safety in Medical Imaging

Islamic Perspectives

In a recent work by the present author ${ }^{1}$, various Islamic perspectives can be used in the integration process. They include (1) Islamic / Tauhidic worldview, (2) basic concepts in Islam and Islamic Faith, (3) Islamic revealed knowledge (Qur'an and Hadith), (4) Maqasid (objectives) and Qawa'id (principles) of the Shari'ah, (5) Muslim ethics and morals, (6) Islamic Jurisprudence (Fiqh), (7) Muslim History and Civilisation, (8) Contribution of Islamic scholars in the various fields of Human Knowledge and (9) thoughts of Muslim scholars. It is to be reiterated that the given list of Islamic perspectives is not exhaustive. Amidst arguments to the use of the term "Islamic perspectives", in its plural form, the term merely reinforce the types, approaches, viewpoints, themes or methodologies to support the discussions. The author wishes to state and maintain that the terms "perspective", "viewpoint" or other similar terms, whether in their singular or plural forms, are used to relate to the types of Islamic essences used as references in the text. These references listed above are meant to direct all discussions ultimately to Allah. In other words, there is only one focal point in the discussions and do not suggest that Islam has a differing opinion, stance or outlook based on different references.

Using the safety domain some major and minor concepts are presented with the alignment of relevant Islamic perspectives. The concept of safety can be aligned to the various Qur'anic verses and hadiths that relate to safety. The micro concept of cross infection can be aligned to the concept of cleanliness from Islamic perspective involving ablution and the hadith that champion cleanliness as part of faith. The experimental setup by Al-Razi (Rhazes) that examined the rate of decay of meat identified the safe place to build a hospital showed the gift of intelligence, and hence the Maqasidic preservation of the mind or intellect in preserving safety to the patients. These are some examples whereby Islamic perspectives can be aligned to the components involving safety in Medical imaging.

\section{Teaching and Learning}

Various teaching methods can be utilised to support the content delivery towards the attainment of identified outcomes. It is felt that the teaching and learning strategies used in conventional educational setting can still be applicable to facilitate the integration of Islamic essences into the theoretical domains of medical imaging. However, considerations must be given to determine the appropriate teaching methodology as the nature of the Islamic perspectives not only addresses the cognitive, affective and psychomotor components but the elements of spirituality and religiosity.
Individual tailoring of well thought approaches to the students, either as a group or as individuals will go beyond the common assumption that a certain teaching methodology is applicable for all.

The success of OBE depends not only on the curriculum design but also on the individualised approaches in the teaching and learning that depend heavily upon the knowledge giver (academician) and the knowledge recipient (student). The effectiveness of the academician lies not only in his mastery in teaching methodologies but also upon his receptiveness to acknowledge the differences in students' learning styles and preferences. Aspects involving the concept of Murabbi (Islamic Education Teacher) could reflect directly towards the success of the integration of Islamic perspectives into Medical Imaging.

\section{Muslim Teacher characteristics}

The work of Tucker and Stronge ${ }^{19}$ outlines the key features of an effective teacher. Beginning with formal training, followed by certification and the subsequent accumulation of teaching experiences, an effective teacher exhibits caring, fair, and respectful disposition. Having high expectations for himself and his students, he maximizes instructional time via effective classroom management and organization. He presents the course content in meaningful ways that fosters understanding by varying instructional strategies, activities, and assignments. Ready to commit extra time to instructional preparation and reflection he monitors students' learning by utilizing pre and post assessments, providing timely and informative feedback. He demonstrates effectiveness in the face of differing student abilities, reteaching material to students who did not achieve mastery. On the other hand, Sidek Baba, a prominent Muslim scholar felt that besides the above teacher qualities, the teacher should arm himself with knowledge, skills, and specialization; acts as a good role model to others, instil good values to students as well as create a conducive atmosphere during the process of teaching and learning. ${ }^{20}$

The Muslim Medical imaging teacher is hereby drawn to the characteristics of the Islamic Education Teacher (IET), the Murabbi, as described in various designations; Mu'allim (teacher), Mu'adib (coach), Mudarrib (trainers), Muwajjih (advisor or counselor) and Murshid (consultants). ${ }^{20}$ These designations describe the Murabbi as knowledge deliverer, social engineer, unity nurturer, mind enhancer, character developer and agent of change. The authors acknowledge the Murabbi as one who educates, with Allah being the key reference and possesses the self-efficacy to teach and educate within the framework of Islamic Education Philosophy. ${ }^{20}$

The Murabbi is further reflected upon the image of Prophet Muhammad (Pbuh) in actions, words, and ideas. ${ }^{21}$ To the author, the prophet "was a fully 'embodied thinker because his activity and 
experience of thinking are neither purely mental nor purely physical, but it was an activity in which their whole being participated'. These elements should be seen within the context of a compilation by Noornajihan et $\mathrm{al}^{20}$ over the inability of Muslim teachers in establishing themselves as mentors and role models to students, the failure to display a complete Islamic way of life and not practicing the holistic nature of interpersonal and intrapersonal positive personality according to Islamic teachings. These situations create doubts among students, fellow teachers, administrators and the public to the image of IET.

The role of the Murabbi in the integration process in Medical imaging can be a challenge. The Muslim teacher needs to acknowledge his certification to practice and upholds the concept of "Ijazah" that carries "the recognition of teaching others". He determines his self-efficacy in his role as a Murabbi; his belief that he can provide effective teaching, belief that he has the skills and ability to bring significant changes to student learning and undertaking the task to educate and assist students in achieving the goals in the Philosophy of Islamic Education. ${ }^{20}$

\section{Student learning styles and preferences}

Learning style denotes the manner individuals choose or inclined to approach a learning situation that will impact on performance and achievement of learning outcomes. ${ }^{22}$ The strategies a person choose while learning depends on the differences in the individuals' psychological attributes that result in different behaviours in the way they perceive, interact, and respond to the learning environment. ${ }^{23}$

The Kolb Learning Style inventory is one of the many learning style models and has remained the wellaccepted measurement tool to measure individual learning preference. ${ }^{24}$ This model categorises students into four learning style groups; Convergers, Divergers, Assimilators or Accommodators. These groups are further described by their learning modes: Concrete Experience (CE), Reflective Observation (RO), Abstract Conceptualization (AC), and Active Experimentation (AE). The learning modes of these respective groups are: (CE) peer orientation and benefited most from discussion with fellow learners, (RO) relied heavily on careful observation in making judgments, (AC) tended to be oriented more towards symbols and learned best in authority-directed, impersonal learning situations, while (AE) tended to be an active, "doing" orientation to learning that relied heavily on experimentation and learned best while engaging in projects. This variety of preferences dictates the need for teachers to understand the kind of students and their preferences in ensuring a successful outcome in the teaching and learning activities.

Another student preference measurement model is VARK model. Introduced by Fleming, it recognises that students have different preferences in the assimilation and processing of information. It classifies students into four different learning modes; visual $(\mathrm{V})$, aural $(\mathrm{A})$, read/write $(\mathrm{R})$, and kinesthetic (K) (Prithishkumar \& Michael, 2014). While there have been reservations to validate VARK statistically, Professor Marilla Svinicki held the opinion that VARK's strength lies in its educational value for helping people think about their learning in multiple ways and giving them options they might not have considered. ${ }^{25}$ Multiple modalities of information presentation may be required in order to keep the attention and motivation of the students. ${ }^{26}$

A study on Muslim students in a religious school found that a good number of Muslim students preferred auditory and visual learning styles and group learning styles. ${ }^{23}$ The assumption was these religious-oriented students had been typically taught in oral lecture format, and are also trained to be good listeners in order to differentiate the Arabic sounds intensively. All these efforts complement the call for teachers to effectively teach according to the needs of the student. Having knowledge on the learners' learning styles not only can improve the classroom instructions but should also be seen in the benefit to students as it would help them in formulating the appropriate learning strategies for enhancing their learning. ${ }^{27}$

The present author holds the belief that there are no studies that have correlated the preferences of the instructional methods pertaining to Islamic perspectives with the learning styles of the Medical Imaging students. This can be attributed that the integration of Islamic perspectives into Medical imaging theory has yet to be realised. The challenge will be to find effective methodologies of integration to the multi-faceted nature of the domains in Medical imaging, and aligning these to the learning styles and preferences of students from varied backgrounds.

\section{Assessment}

A variety of assessment approaches is needed to assess the knowledge, skills, and values. ${ }^{7}$ The assessments should satisfy the learning objectives and fulfil the expectations as outlined by the domains of learning. The subject matter delivered during the teaching must be aligned to the items that appear in the assessment. ${ }^{17}$ The Tognolini Report emphasised the need for a coherent relationship between specific assessment procedures and identified outcomes. ${ }^{12}$ Action verbs that are used to describe the taxonomies of Bloom (cognitive domain), Krathwohl (affective domain) and Harrow (psychomotor domain) for a given course can be used to formulate the questions for the assessment.

The above methods to determine whether learning has taken place can be replicated and may still be 
applicable to certain dimensions of the integration of Islamic perspectives. However, their applications might be limited in assessing areas involving Islamic spirituality and religiosity since these dimensions are areas that have remained segregated from the theoretical domains. Suhaila ${ }^{21}$ argues that Muslims' actions and judgments cannot be empirically measured for those actions and judgements are made based on faith. However, several Muslim scholars have proposed several assessment tools that serve to evaluate certain spiritual and religious dimensions involving the Muslim individual. They include the Muslim Religiosity-Personality Inventory $(\text { MRPI })^{2}$, Psychological Measure of Islamic Religiousness (PMIR) ${ }^{29}$, Islamic Behavioral Religiosity Scale $(\text { IBRS })^{30}$, Ummatic Personality Inventory $(\mathrm{UPI})^{31}$, Moral Character of Muslim Personality $\left(\right.$ MCMP $^{32}$, Integrative Islamic Personality Inventory (IIPI) $)^{33}$ and the Five Dimensions of Muslim religiosity ${ }^{34}$. These depict the commitment of Muslim scholars to provide some valuable assessment tool to evaluate one's connectedness to the Creator as well as the performance of religious rituals that could cement one's belief and submission to Allah. Examining the mentioned assessment tools can pave the way for the development of assessment tool to study for the effectiveness of the integration process.

\section{CONCLUSION}

The proposed framework above shows the possible alignment of an integration process to a currently accepted philosophy of education. It provides the direction of integration involving the theoretical domains of a multifaceted discipline to relevant Islamic essences. These essences, in all practicality for the integration, eventually relates to Allah, the Creator. Systematically done, the framework can provide the desirable coherence to both the human sciences and the Islamic paradigm. Rather than merely accepting the rejection of certain quarters towards the concept of OBE, lessons learned from past OBE adoptions can be used to benefit the integration initiative. Adopting strict documentation of the elements of OBE, the involvement of relevant staff and understanding teacher and student characteristics are elements that could further enhance the success of the integration. It is hoped that the integration of Islamic essences into a typical curriculum in any discipline can now be systematically done.

\section{REFERENCES}

1. Zainul IZ. A Thematic Study Of Islamic Perspectives In Scopus Indexed Articles. Implications on Medical imaging. Library Philosophy and Practice (e-journal). ISSN 15220222. Libraries at University of Nebraska-Lincoln 2015. Available at http://digitalcommons .unl.edu/ libphilprac/1233/ Accessed July 25, 2016

2. Solehah $\mathrm{Y}$, Rahimah E. The concept of an integrated Islamic curriculum and its implications for contemporary Islamic schools. In: Islamic solidarity in Education, 20-22 February 2008, Tehran, Iran. Available at http://irep.iium.edu.my/2470/ Accessed July 7, 2016

3. Yazicioglu I. Perhaps Their Harmony is not that Simple: Bediuzzaman Said Nursi on the Qur'an and Modern Science. Theology and Science 2013; 11(4), 339-355, Available at DOI:10. 1080/ 14746700.2013.836888.

4. Rippin A. The Islamic World. New York; Routledge. 2008

5. Khairiah O, Engku Haliza El, Ainon Jariah M, Isarji S. Inculcating Islamic values in teaching western short stories to Muslim learners. In: Language studies in the Muslim world. IIUM Press, Kuala Lumpur, pp. 83-111. 2011. Available at http://irep.iium.edu.my/id/eprint/1381 Accessed July 72016

6. Zuraida A, Ahmad FI, Amir AS, Sany II, Zahurin $\mathrm{H}$, Souad AMA. Islamisation of engineering education in International Islamic University Malaysia (IIUM): problems and prospect. Revelation and Science 2011; 1 (3); 131-137.

7. Malan SPT. The 'new paradigm' of outcomesbased education in perspective. Journal of Family Ecology and Consumer Sciences 2000; Vol 28. Available at http://wings.buffalo. edu/ubtlc/ resources/ Outcomesbased_education.pdf Accessed July 20,2016

8. Jayarekha P, Dakshayini M. Programme outcomes assessment by direct method. IEEE International Conference on MOOC, Innovation and Technology in Education (MITE), 2014. Available at http:// ieeexplore .ieee.org/stamp /stamp.jsp?tp =\&arnumber $=7020285$ Accessed July 18, 2016

9. Lui G, Shum C. Outcome-based education and student learning in managerial accounting in Hong Kong. Journal of Case Studies in Accreditation and Assessment 2012; Vol. 2, p1. Available at http://www.aabri.com/manuscripts/10562.pdf Accessed July 18,2016

10. Davis MH. Outcome-Based Education. JVME 2003; 30(3). Available at http://www.jfn .ac.lk/OBESCL/MOHE/OBE-Articles/Academicdocuments-articles/6.OBE-Davis.pdf Accessed July 16, 2016

11. Morcke AM, Dornan T, Eika B. Outcome (competency) based education: an exploration of its origins, theoretical basis, and empirical evidence. Adv Health Sci Educ Theory Pract. 2013; Oct;18(4):851-63. Available at doi: 10.1007/s10459-012-9405-9. Epub 2012 Sep 18.

12. Lawson MJ, Askell-Williams H. . Outcomes Based Education. Centre for the Analysis of Educational Futures. Flinders University. 2007. Available at

http://www.ais.sa.edu.au/_files/f/2128/Outc omes\%20Based\%20Education.pdf Accessed July 27, 2016

13. Ali AY. The Meaning of The Holy Qur'aan. Text, Translation and Commentary. Kuala Lumpur: 
Islamic Book Trust 2009 International Islamic University Malaysia. IIUM Policies and Guidelines on Islamisation. Kuala Lumpur. Centris 2013 Available at http://www.iium.edu.my/sites / default/ files/IIUM\%20POLICIES\%20AND\%20GUIDELINES\%2 0ON\%20ISLAMISATION.pdf.pdf Accessed July 12,2016

14. Mamat MR, Rasul MS, Mustapha A. OutcomeBased Education Implementation In Malaysian Polytechnic. International Journal of Education and Research. 2014; Vol. 2 No. 11.

15. Crespo RM, Najjar J, Derntl M, Leony D, Neumann S, Oberhuemer P, Totschnig M, Simon $B$, Gutiérrez I, Kloos CD. Aligning assessment with learning outcomes in outcome-based education. IEEE EDUCON 2010 Conference. Available at http:/ / ieeexplore.ieee.org/stamp/stamp.jsp?tp =\&arnumber $=5492385$ Accessed July 17, 2016

16. Webb EM, Naeger DM, Fulton TB, Straus CM. Learning objectives in radiology education: why you need them and how to write them. Acad Radiol. 2013 Mar;20(3):358-63. Available at doi: 10.1016/j.acra.2012.10.003

17. Malaysian Qualification Agency. (2016). Programme Standards: Medical and Health Sciences. Malaysian Qualifications Agency. Pg 108-110 Available at http://www.mqa.gov.my/QAD/PS/ PS\%20Medical\%20BI.pdf Accessed July 18,2016

18. Tucker PD, Stronge JH. Linking Teacher Evaluation and Student Learning. Association for Supervision and Curriculum Development. 2005. Available at http://www.ascd.org/publications /books /104136/chapters/The-Power-of-anEffective-Teacher-and-Why-We-Should-AssessIt.aspx Accessed 8.8.2016

19. Noornajihan J, Ab. Halim T, Nurul Asiah Fasehah M, Norzulaili MG, Robiatul Adawiyah M, Norakyairee MR, Syed Najihuddin SH. The Importance of Self-Efficacy : A Need For Islamic Teachers as Murabbi. Procedia - Social and Behavioral Sciences 2012: 69,359 - 366.

20. Suhailah $\mathrm{H}$. Towards the development of a murabbi. In: Teachers' learning, curriculum innovations and knowledge applications. Universiti Putra Malaysia Press, Serdang, Selangor., 2009 pp. 73-87. ISBN 9789673440900 Available at http://irep .iium.edu.my/7026/1/UPMteachersLEARNING[06 ].pdf

21. Cassidy S. Learning styles: An overview of theories, models and measures. Educational Psychology 2004: Vol 24 (4). 419 - 443

22. Mohamad Jafre ZA, Abbas AR, Helan NA and Kiranjit KBS. Learning Styles and Overall Academic Achievement in a Specific Educational System. International Journal of Humanities and Social Science 2011; Vol. 1 No. 10; 143-152

23. Lu H, Jia L, Gong SH, Clark B. The Relationship of Kolb Learning Styles, Online Learning Behaviors and Learning Outcomes. Educational Technology \& Society, 2007; 10 (4), 187-196

24. Fleming N, Baume D. Learning Styles Again:
VARKing up the right tree!, Educational Developments, SEDA Ltd 2006; Issue 7.4, p 4-7.

25. Prithishkumar IJ, Michael SA. Understanding your student: Using the VARK model. J Postgrad Med, 2014; 60:183-6

26. Kharb P, Samanta, PP, Jindal M, Singh V. The Learning Styles and the Preferred TeachingLearning Strategies of First Year Medical Students. Journal of Clinical and Diagnostic Research. 201;3 June Vol-7(6): 1089-1092

27. Krauss SE. Development of the Muslim Religiosity-Personality Inventory for Measuring the Religiosity of Malaysian Muslim Youth. 2005. Available at http://core.ac.uk / download /pdf/ 12225865 .pdf. Accessed November 13, 2015

28. Abu-Raiya H, Pargament KI, Mahoney Al, Stein G. A Psychological Measure of Islamic Religiousness: Development and Evidence for Reliability and Validity. International Journal for the Psychology of Religion, 2008; 18(4), pp. 291-315.

29. Abou-Youssef $M$, Kortam W, Abou-Aish E, ElBassiouny N. Measuring Islamic-Driven Buyer Behavioral Implications: A Proposed MarketMinded Religiosity Scale. Journal of American Science 2011;7(8). Available at http: //www. jofamericanscience. org/journals/am-sci /am0708/ 085_6637am0708_728_741.pdf Accessed July $24, .2016$

30. Othman N. Exploring the Ummatic Personality Dimensions from the Psycho-spiritual Paradigm. International Journal of Psychological Studies, 2011; Vol 3, No. 2. Available at http://www. ccsenet.org/journal /index.php /ijps/ article / view/13335/9202 Accessed August 3,2016

31. Al-Ammar FK, Ahmed IH, Nordin MS. Moral Character of Muslim Personality: Scale Validation. Journal of Education and Practices 2012: 3(16), pp.118-128.

32. Ismail NA, Tekke M. Development and Initial Validation of Integrative Islamic Personality Inventory. Adv. Environ. Biol. 2015; 9(18), pp. 163-171.

33. El-Menouar Y. The Five Dimensions of Muslim Religiosity. Results of an Empirical Study. methods, data, analyses 2014; Vol. 8(1), pp. 5378 Available at DOI: $10.12758 / \mathrm{mda} .2014 .003$ 